\title{
洗濯における電解水の洗浄効果
}

\author{
島根大学教育学部 高橋哲也・麻生祐司 \\ 島根大学生物資源科学部 山本達之
}

\section{Detergency of Electrolysis Water in Laundering}

\author{
Tetsuya Takahashi ${ }^{* 1}$, Yuji Aso ${ }^{* 1}$, and Tatsuyuki Yamamoto ${ }^{* 2}$ \\ ${ }^{* 1}$ Faculty of Education, Shimane University, Matsue, 690-8504, Japan \\ ${ }^{* 2}$ Faculty of Life and Environmental Science, Shimane University, Matsue, 690-8504, Japan
}

\begin{abstract}
The detergency of electrolysis water in laundering was studied. First, contact angle with cellophane and PET films was measured. In both films, the contact angle decreased with increasies in the $\mathrm{pH}$ of electrolysis water. Electrolysis water of $\mathrm{pH} 11$ was absorbed nearly completely by cellophane in 30 minutes. In addition, various kinds of water were examined for water absorption by fabrics. The absorption rate of electrolysis water of $\mathrm{pH} 11$ was more rapid than other kinds of water. It was found to possess very high permeability into the fabrics.

Artificial soiled fabrics were laundered in various kinds of water. The result revealed that electrolysis water of $\mathrm{pH}$ 11 showed high detergent efficiency for such hydrophilic materials such as cotton, silk, and wool that were artificial soiled fabrics. Furthermore, when sodium dodecylbenzenesulfonate, a surfactant, was added to launder them, detergent efficiency was further improved by the addition of sodium dodecylbenzenesulfonate. Surfactant decomposition by active oxygen formed was not inferred to take place much in laundering in electrolysis water from this finding.

In addition, a test was performed to examine soil redeposition in cotton and polyester fabrics with water-soluble and oil-soluble soil. It was found difficult to redeposit soil in them when laundering them in electrolysis water of $\mathrm{pH} 11$. However, although the cotton and polyester fabrics were not found much damaged after laundering, the wool fabric was observed to be damaged when electrolysis water $(\mathrm{pH}=11)$ was used. The extent of damage was about the same as that found when a sodium hydroxide solution $(\mathrm{pH}=11)$ was used instead.
\end{abstract}

(Received 28 September, 2005 ; Accepted 18 December, 2006)

\section{1. 緒 言}

近年, 河川，湖，地下水などの污染が社会問題となり， 合成洗剤の環境に与える影響について様々な研究がなさ れている[1-3]. また, 界面活性剤の魚類に対する急性毒 性[4]や, 漂白剂に対しても危険性と処理方法が研究され ている $[5]$. さらに，石鹸粕を栄養源とする洗濯機内部の 徽に関しても研究されている $[6]$.

一方, 電解水による洗濯が注目され[7], 商品化がなさ れている $[8]$. これらは電解水を用いることによって, 洗 剤の使用量を削減することを目的としたものである。し かし，その有効性については様々な議論が行われている。 電解水の洗浄作用としては, 発生した活性酸素や次亜塩 素酸ナトリウムによる污れ物質の分解が主に論じられて いる. そのため, 電解水を用いた洗濯では界面活性剤が 活性酸素や次亜塩素酸ナトリウムによって分解されると 考えられるため, 洗剤を使用しても洗浄効果の向上には 必ずしも寄与しないとされている。電解水と界面活性剂
の併用効果などについても, その効果を詳細に明らかに する必要がある。また, 繊維素材の種類による有用性の 差についても, 充分に論じられているとは云えない. 本 研究では, 異なる繊維素材の人工污染布を用い, 電解水 の洗濯に対する効果について詳細に研究した.

\section{2. 実 験}

\section{1 試料}

\subsection{1 人工污染布}

米国テストファブリック社製・人工污染布(綿, ポリエ ステル, ウール, 絹, アクリル)を用いた。これらを $5 \times 5 \mathrm{~cm}$ の大きさに裁断して使用した。また, 污れ成分による相 異に対する影響についても検討す心゙く, 洗濯科学協会製 の綿の人工污染布も比較として用いた. 表 1 に, 実験に 使用した人工污染布の污垢成分を示す.

\subsection{2 織物}

株式会社色染社製・綿ブロード未シルとポリエステル タフタを用いた。なお，両布地とも平織物の白布である. 
Table 1 Composition of paste for artificial soiled fabrics.

\begin{tabular}{lr|lc}
\hline \multicolumn{2}{c|}{ Testfablics Inc. (USA) } & & Laundry Research Association (Japan) \\
\hline \hline Kelex (Sodium alginate thickepet) & $1.30 \%$ & Oleic acid & $24.50 \%$ \\
Corn starch (\#10 Pearl Starch) & $2.20 \%$ & Triolein & $20.90 \%$ \\
Water (N.J. tap) & $72.40 \%$ & Cholesterololeate & $16.00 \%$ \\
Mineral oil (Penreco Drakeol \#21) & $14.00 \%$ & Liquid paraffin & $3.10 \%$ \\
Oleic acid & $0.42 \%$ & Squalene & $3.10 \%$ \\
Morpholine & $0.36 \%$ & Cholesterol & $2.10 \%$ \\
Vegitable fat & $1.70 \%$ & Inoranic dirt (clay) & $29.80 \%$ \\
(Unemulsified Covo -Lever Bros.) & & Carbon black & $0.50 \%$ \\
Butanol & $0.30 \%$ & & \\
1,2,4-Trimethyl benzene and Napthtna & $4.40 \%$ & & \\
Ethyl cellulose & $0.70 \%$ & & \\
Carbon black (Degussa) & $0.70 \%$ & & \\
\hline
\end{tabular}

各々の布地の織構造を下記に示す。

$$
\begin{gathered}
\text { 綿ブロード未シル： (1) 䒺密度 (経糸) } 130 \text { 本/インチ } \\
\text { (緯糸) } 70 \text { 本/インチ } \\
\text { (2)目付け } 122.5 \mathrm{~g} / \mathrm{m}^{2}
\end{gathered}
$$

ポリエステルタフタ：(1)糸密度 (経糸) 120 本/インチ

(緯糸) 90 本/インチ

\section{(2)目付け $71.8 \mathrm{~g} / \mathrm{m}^{2}$}

\subsection{3 フィルム}

接触角の測定のため, 二村化学工業株式会社製・普通 セロハン\#500(厚さ $38 \mu \mathrm{m}$ ) と，帝人デュポンフィルム株式 会社製・テイジンテトロンフィルム(厚さ $175 \mu \mathrm{m})$ を用い た。両フィルムとも表面処理は施されていない.

\section{2 電解水の作製}

ホシザキ電気株式会社製・調理用電解水生成器 HOX$40 \mathrm{~A}$ を用い, 蒸留水に和光純薬工業株式会社製・塩化ナ トリウム試薬 (特級)を $10 \mathrm{ppm}$ 加えて電気分解を行った. 本装置は，隔膜を介して陽極液と陰極液が分離されてい るタイプである。陰極側に生成された $\mathrm{pH}$ が 7，9，11の アルカリ性電解水を採取した。比較として, 蒸留水に関 東化学株式会社製・水酸化ナトリウム試薬(鹿 1 級)を適 量加えた $\mathrm{pH} 11$ の水酸化ナトリウム水溶液も作製した. なお, 電解水は作り置きせず, 洗濯直前に生成して使用 することとした。

\section{3 污染布の作製方法}

2.1.2 項に示した綿とポリエステルの織物を所定の大き さ $(5 \times 5 \mathrm{~cm})$ に裁断した。食事中に付着する污れを想定し， 蒸留水に合成食用色素の食用赤色 2 号 (Amaranth) と食用 黄色 2 号 (Tartrazine) を加えて, $0.25 \mathrm{wt} \%, 0.51 \mathrm{wt} \%$ の濃度 の污染液を各々作製した。 その污染液に, 裁断した織物 を 15 秒每に表裏反転を 4 回繰り返し, 計 1 分間污染した. 污染後の織物を 24 時間以上風乾した。 その後, 島津製作 所株式会社製・島津自記分光光度計 UV-3100 を用いて, $530 \mathrm{~nm}$ の反射率を測定した。なお，以下に污れ物質とし て使用した食用赤色 2 号と食用黄色 2 号の化学式を示す.
Amaranth : $\mathrm{C}_{20} \mathrm{H}_{11} \mathrm{~N}_{2} \mathrm{O}_{10} \mathrm{~S}_{3} \mathrm{Na}_{3}$

Tartrazine : $\mathrm{C}_{16} \mathrm{H}_{6} \mathrm{~N}_{4} \mathrm{O}_{9} \mathrm{~S}_{2} \mathrm{Na}_{3}$

\section{4 測定方法}

\section{4.1 電気伝導度}

株式会社堀場製作所製・カスタニー ACT 導電率メー ターES-12 を用い, 各々の水に導電率電極を挿入し, $2 \% /{ }^{\circ} \mathrm{C}$ $\left(\right.$ at $\left.25^{\circ} \mathrm{C}\right)$ の温度係数で $25^{\circ} \mathrm{C}$ の換算伝導率值を測定した。

\section{4.2 表面張力}

太平理化工業株式会社製・デュヌーイ氏表面張力計を 用いた。液体表面に接触させた金属環と涎面が離れる瞬 間の力をピアノ線の㸚じれにより検出した。また，この 時の液温を温度計で測定した。測定は 5 回行い, その平 均值から表面張力を算出した。 なお, 測定に用いたエチ ルアルコールは, 関東化学株式会社製試薬(特級, 純度 99.5\%)である。

\section{4.3 接触角}

フィルム上に，マイクロシリンジにて $10 \mu \mathrm{l}$ の液滴を滴 下した，そして，エルマ光学株式会社製・ゴニオメーター 式エルマ接触角測定機 $\mathrm{G}-1$ 型を用いて, 滴下 1 分後から の小滴映像をとらえた。ゴニオメーター分度器にて, 円 弧系の一端の接触角を経過時間ごとに読み取った.

\section{4.4 バイレック法による吸水速度評価}

織物を経糸が長尺方向になるように短冊状 $(25 \times 2.5 \mathrm{~cm})$ に裁断した。 そして, 東洋精機株式会社製・吸水速度試 験機を用いて, 1 分後からの毛細管現象による水の上昇し た高さ $(\mathrm{mm})$ を経過時間ごとに測定した。測定は 5 回行い, その平均值を算出した。 なお，次亜塩素酸ナトリウム水 溶液は, 関東化学株式会社製試薬( 鹿 1 級, 有効塩素量 5.98\%)を用いて所定濃度に調整して作製した。

\section{4.5 洗浄性の評価}

界面活性郕として, 所定量のドデシルベンゼンスルフォ ン酸ナトリウム $(\mathrm{DBS})$ を各種の水 $100 \mathrm{ml}$ と共に洗浄瓶に 入れ, $40^{\circ} \mathrm{C}$ の温水に 10 分間浸漬して温度を一定にした。 
Table 2 Electric conductivity for different water.

\begin{tabular}{cccccc}
\hline \multirow{2}{*}{ Sample } & & & & $($ Unit : $\mu \mathrm{S} / \mathrm{cm})$ \\
\cline { 2 - 4 } & $\mathrm{pH}=7$ & $\mathrm{pH}=9$ & $\mathrm{pH}=11$ & Distilled water & $\begin{array}{c}\text { NaOH solution } \\
(\mathrm{pH}=11)\end{array}$ \\
\hline \hline \multirow{2}{*}{ Electric conductivity } & 202 & 204 & 317 & 2 & 114 \\
\hline
\end{tabular}

Water temperature : $25^{\circ} \mathrm{C}$

その後, 洗浄瓶に污れ物質で污染した 2 枚の織物や人工 污染布 $(5 \times 5 \mathrm{~cm})$ を直径 $5 \mathrm{~mm} \phi$ の鋼球 10 個と共に入れ, 興亜商会株式会社製・KL-8 型ラウンダ・オメーターを用 いて, 温度 $40^{\circ} \mathrm{C}, 30$ 分間, 回転数 $42 \mathrm{rpm}$ の条件にて洗濯 を行った。その後, 洗濯と同じ水を用いて 3 分間 $\times 2$ 回の す寸ぎを行い, 風乾した。風乾後, 島津製作所株式会社 製・島津自記分光光度計 UV-3100を用いて, 530nm の反 射率を測定した。污染前の白布の反射率を基に, 次式よ り洗浄効率を算出した。洗濯は 1 つの試料について 3 回 以上行い, その平均值で表すこととした。

洗浄効率 $(\%)=\left(\mathrm{R}_{w}-\mathrm{R}_{\mathrm{s}}\right) \times 100 /\left(\mathrm{R}_{0}-\mathrm{R}_{\mathrm{s}}\right)$
$\mathrm{R}_{\circ}$ : 污染前の白布の表面反射率
$\mathrm{R}_{\mathrm{s}}$ : 污染布の表面反射率
$\mathrm{R}_{w}$ : 洗浄布の表面反射率

なお，使用した DBS は，関東化学株式会社製の試薬(鹿 1 級)である。

\section{4.6 再污染性の評価}

米山薬品工業株式会社製のカーボンブラック，和光純 薬工業株式会社製試薬の $\alpha$-酸化鉄 (III) (純度 99.9\%) を 各々 $0.01 \mathrm{~g}, 0.10 \mathrm{~g}$ を量り取って各種の水 $100 \mathrm{ml}$ と共に洗 浄瓶に入れ, マグネチックスターラーで 1 時間擋拌して 污染液を作製した。洗浄は前項 2.4 .6 と同様の方法で行い, 洗浄試験前の白布の反射率を基に, 次式より再污染率を 算出した. 使用した織物は2.1.2 項に示した白布である. 洗浄試験前の白布の反射率を基に, 次式より再污染率を 算出した.

再污染率 $(\%)=\left(\mathrm{R}_{0}{ }^{\prime}-\mathrm{R}_{\mathrm{w}}{ }^{\prime}\right) / \mathrm{R}_{\mathrm{o}}{ }^{\prime} \times 100$

$\mathrm{R}_{0}{ }^{\prime}$ : 再污染用布の洗浄試験前白布の反射率

$\mathrm{R}_{\mathrm{w}}{ }^{\prime}$ : 再污染用布の洗浄試験後の反射率

\section{3. 結果及び考察}

\section{1 水の電気伝導度と表面張力}

実験に使用する水に含まれている不純物の割合や水分 子の電離状態について調べるべく, 各種の水の電気伝導 度を調べた。 その結果を表 2 に示す。蒸留水では $2 \mu \mathrm{S} / \mathrm{cm}$ と, 電気伝導度が極めて小さかった。このことは, 蒸留 水には不純物の含有量が極めて少ないことを意味してい る. 一方, 電解水では, どの $\mathrm{pH}$ の水でも電気伝導度が比 較的高かった。電解水は電荷移動に伴って $\mathrm{H}^{+}$イオンと $\mathrm{OH}^{-}$ イオンを生じ, $\left[\mathrm{H}^{+}\right]\left[\mathrm{OH}^{-}\right]=10^{-14}$ を満足する安定な平衡状 態にある.また, pH11 の水酸化ナトリウム水溶液では,
$\mathrm{Na}^{+}$イオンと $\mathrm{OH}^{-}$イオンに電離するために蒸留水よりも高 い電気伝導度 $(114 \mu \mathrm{S} / \mathrm{cm})$ を示したが, 同じ $\mathrm{pH}$ の電解水 $(317 \mu \mathrm{S} / \mathrm{cm})$ と比べると $1 / 2$ 以下と低いこともわかった.

次に，各種の水の表面張力について調べた。その結果 を表 3 に示す. 蒸留水, 各種の電解水, 水酸化ナトリウ 厶水溶液 $(\mathrm{pH}=11)$ の表面張力には, あまり差が認められ なかった。 つまり, 水そのものには表面張力に本質的な 差が無いものと考えられる。一方, 界面活性剤である DBS を添加すると, 水の種類に関係なく $1.6 \times 10^{-4} \mathrm{~mol} / 1$ 添加で は 40dyne $/ \mathrm{cm}$ 程度, $5.0 \times 10^{-4} \mathrm{~mol} / 1$ 添加では $33 \mathrm{dyne} / \mathrm{cm}$ 程 度にまで表面張力は低下した。また，比較として調べた エチルアルコールも $26.1 \mathrm{dyne} / \mathrm{cm}$ であり, 水に比べると非 常に小さな值であることが確認できた.

\section{2 水の接触角亡布地への吸水性}

電解水の洗浄効果を調べるにあたり, 先ず水そのもの と綿布やポリエステル布との親和性を調べる必要がある. そこで, 界面活性剤を添加していない水について, 接触 角を基にして検討を行った。接触角の測定に際しては, 綿はその化学構造がセルロースであるために平板材料と してセロハンを, ポリエステルでは表面処理をしていな いPETフィルムを各々使用した。図 1 にセロハンを用い た場合の結果を，図２にPETフィルムを用いた場合の結 果を各々示す.

セロハンを用いた場合, 1 分後の接触角の值はどの水に おいても $10^{\circ}$ 未満と極めて小さく, セルロースと水には 高い親和性が認められた。また, 蒸留水と水酸化ナトリ ウム水溶液 $(\mathrm{pH}=11)$ の間には, 接触角にあまり差が無かっ た. 一方, 電解水では $\mathrm{pH}$ が 7, 9, 11 と高くなるのに従っ て, 接触角が小さくなっている. これは, 電解水の $\mathrm{pH}$ が 高くなるのに従って, セルロースとの親和性が高くなる ことを示している.

また，どの水においても接触角は時間の経過と伴に低 下していることもわかる. 30 分後の接触角の值は, 蒸留 水, 水酸化ナトリウム水溶液 $(\mathrm{pH}=11), \mathrm{pH} 7$ の電解水で は3〜 $4^{\circ}$ 程度であるのに対して, $\mathrm{pH} 9$ の電解水では $2^{\circ}$, $\mathrm{pH} 11$ の電解水では $0.5^{\circ}$ と小さくなっている. 特に $\mathrm{pH} 11$ 電解水では，他の水に比べてセロハンとの親和性が非常 に高く, 30 分後にはセロハンの表面に大きく広がってほ ぼ吸収されている状態であった。

次に, PETフィルムを用いて同様に接触角を測定した。 PET フィルムを用いた場合, 1 分後の接触角の值はどの水 でも $60^{\circ}$ 程度と高く現れた。また，水の種類による差は 
Table 3 Surface tension for different water.

( Unit : dyne/cm )

\begin{tabular}{|c|c|c|c|c|c|c|}
\hline \multirow{2}{*}{ Sample } & \multicolumn{3}{|c|}{ Electrolysis water } & \multirow{2}{*}{ Distilled water } & \multirow{2}{*}{$\begin{array}{l}\mathrm{NaOH} \text { solution } \\
\quad(\mathrm{pH}=11)\end{array}$} & \multirow{2}{*}{ Ethyl alcohol } \\
\hline & $\mathrm{pH}=7$ & $\mathrm{pH}=9$ & $\mathrm{pH}=11$ & & & \\
\hline Without DBS & 72.6 & 72.9 & 72.2 & 72.1 & 69.4 & 26.1 \\
\hline With DBS $\left(1.6 \times 10^{-4} \mathrm{~mol} / \mathrm{l}\right)$ & 40.3 & 40.5 & 39.5 & 39.9 & - & - \\
\hline With DBS $\left(5.0 \times 10^{-4} \mathrm{~mol} / \mathrm{l}\right)$ & 33.1 & 32.7 & 33.5 & 33.2 & - & - \\
\hline
\end{tabular}

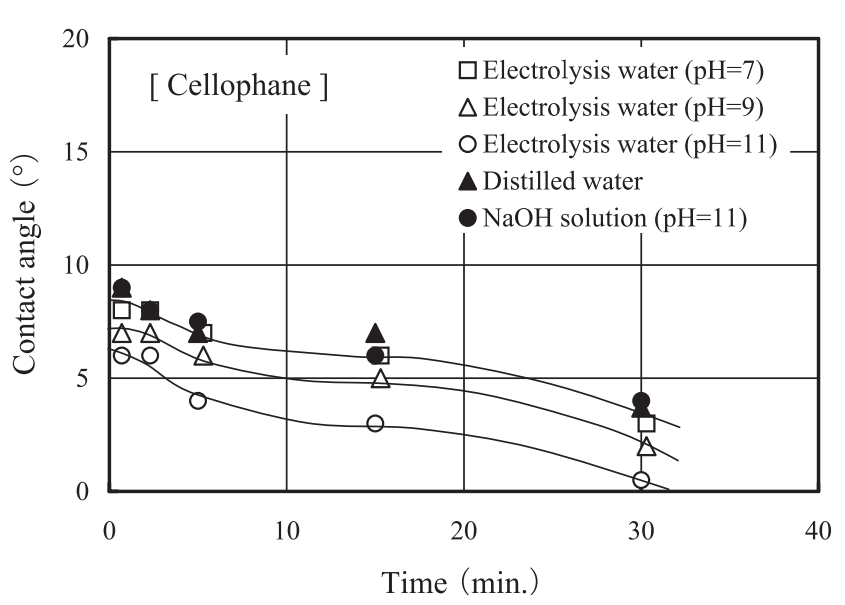

Fig. 1 Time dependence of contact angle for different water on Cellophane.

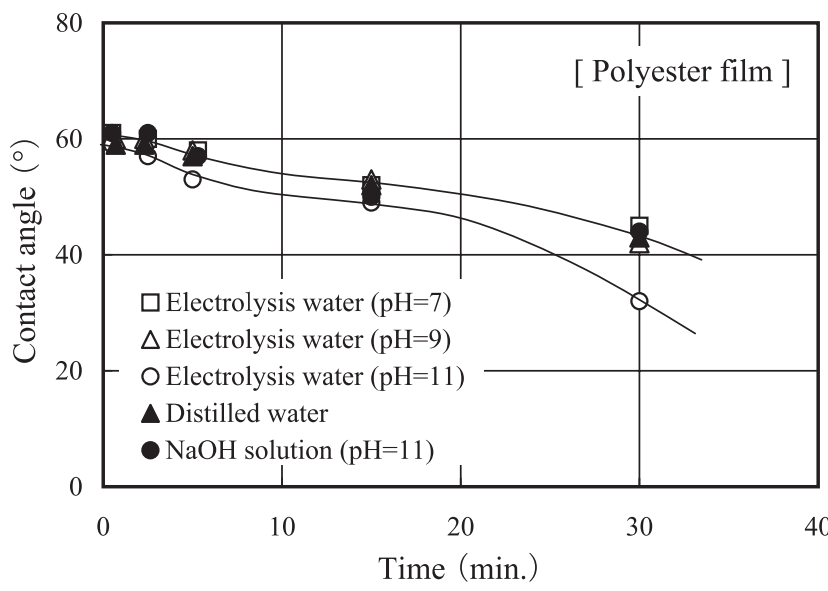

Fig. 2 Time dependence of contact angle for different water on Polyester film.

比較的小さかった。接触角は時間経過と共に低下し，30 分後では pH 11 の電解水を除く全ての水で $42 \sim 45^{\circ}$ 程度 となった。一方, $\mathrm{pH} 11$ の電解水の接触角は $32^{\circ}$ にまで低 下し，他の水に比べてより小さくなっていた。このこと は, pH 11 の電解水では, 他の水に比べてセロハンと同様 に比較的高い親和性が見られたことを示している。この ように, pH 11 の電解水は，ポリエステルに対しても親和 性が比較的高いと云える。前述のように，水の表面張力 には水の種類によってあまり差は見られなかった。しか し, 平板材料との親和性には水の種類によって明らかな 差が見られている. 以上のことから, pH 11 の電解水を洗 濯に使用した場合には, 親水性, 疎水性の繊維とも繊維 内部にまで水が浸透しやすく, 洗浄効果を高められるも
のと期待できる.

次に，布地に対する各種の水の吸水性について調べた。 親水性である綿布と疎水性であるポリエステル布に対し て，バイレック法で吸水高さを測定した。綿布に対する 吸水高さの時間変化を図 3 に，ポリエステル布に対する 時間変化を図 4 に各々示す。 その結果, 綿布, ポリエス テル布の場合とも開始直後から水の種類による差が現わ れ始め, 時間経過とともに吸水高さの差が広がった。 ど ちらの布地であっても $\mathrm{pH} 11$ の電解水では最も吸水性が 高く, 次に $\mathrm{pH} 9$ の電解水が高かった。 また, $\mathrm{pH}$ 值が同 じ 11 の水であっても, 電解水は水酸化ナトリウム水溶液 に比べて吸水性が高い, 一般に, 塩化ナトリウムの含ま れた水を電気分解すると水酸化ナトリウムが生成される ものと考えられる. しかし, 電解水の方が水酸化ナトリ ウム水溶液よりも明らかに吸水性が高いことから, 水酸 化ナトリウムの生成はあまり多くないものと推定できる. 蒸留水は水酸化ナトリウム水溶液よりも低くなっている。 また, 綿布とポリエステル布を比較すると, 吸水高さは 綿布の場合の方がポリエステル布の場合よりも 4〜6倍ほ ど高く現れている. しかし, どちらの布地であっても水 の種類による傾向は同様であった.

一般に, 電解水による洗浄作用として, 次亜塩素酸ナ トリウムの発生が関与するものと考えられている.そこ で，蒸留水に次亜塩素酸ナトリウムを加えた水溶液を作 製し, 次亜塩素酸ナトリウム濃度の違いによる綿布とポ リエステル布への吸水速度の影響を調べた。図 5 に, 10 分後における次亜塩素酸ナトリウム水溶液の上昇した吸 水高さの結果を示す。その結果, 綿布, ポリエステル布 のどちらにおいても, 次亜塩素酸ナトリウム水溶液の濃 度の違いによる差は見られなかった。つまり, 次亜塩素 酸ナトリウムは布地への吸水速度に全く影響していない ことがわかる.さらに, 経過時間ごとの吸水高さも調べ たが，濃度の違いによる吸水速度の差に及ぼす影響は殆 ど見られなかった。この結果は, 綿布, ポリエステル布 とも同じであった。

以上のように, pH 11 の電解水は他の水に比べて明らか に布地への浸透性が非常に高いことがわかった。また, $\mathrm{pH}$ 值が同じ水酸化ナトリウム水溶性や次亜塩素酸ナトリウ ムを含んだ水溶液であっても, 布地への浸透性がアルカ リ性電解水ほど高くないこともわかった。

\section{3 DBS 添加水の洗浄効率}

繊維素材の異なる人工污染布に対して, 各種の水を用 


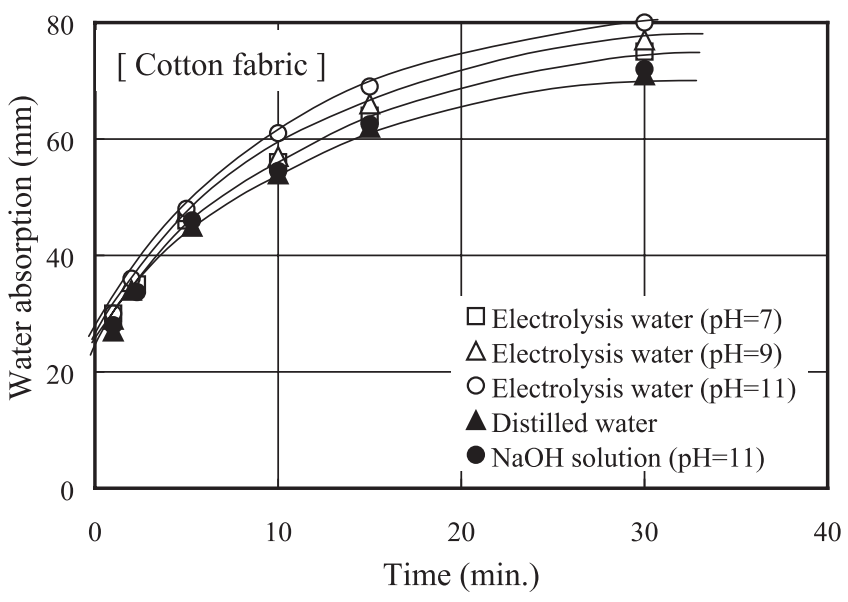

Fig. 3 Time dependence of water absorption for different water on Cotton fabric.

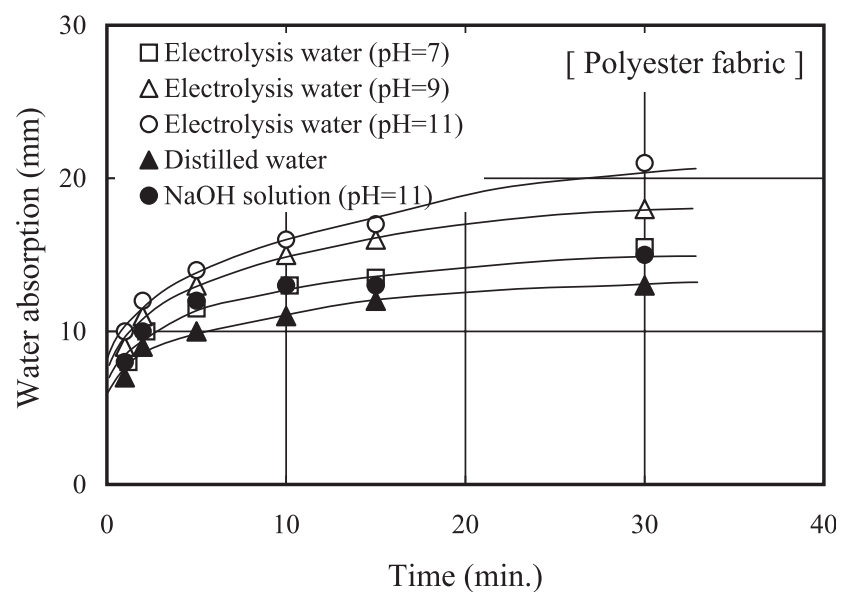

Fig. 4 Time dependence of water absorption for different water on Polyester fabric.

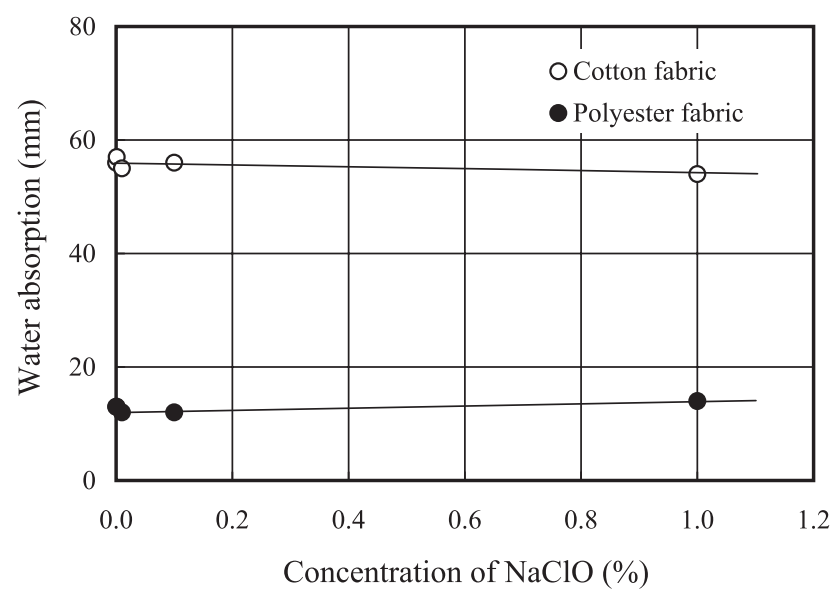

Fig. 5 Relationship between concentration of Sodium Hyprochlorite and water absorption after 10 minutes by Bileck suction tester.

いて洗濯を行った。 その結果を表 4 に示す。界面活性剂 を全く添加せずに水のみで洗濯を行った場合, ポリエス テル布を除いた全ての布地において $\mathrm{pH}$ が 7 や 9 の電解水 を用いた方が蒸留水で洗濯した場合よりも污れが除去さ れていた.さらに pH 11 の電解水になると污れがより除
去されており，洗浄効果は高くなっている．ここで注目 されることは, $\mathrm{pH}$ が 7〜9 と 11 の電解水には比較的大き な差があることである，特に，綿布ではその傾向が強く 現れている.

一方，水酸化ナトリウム水溶液 $(\mathrm{pH}=11)$ においても, 洗浄効率が蒸留水に比べて高く現れている。このことは, 主にアルカリ鹸化作用による[9]。しかし， pH が同じ 11 の水であっても, 水酸化ナトリウム水溶液と電解水を比 べると電解水を用いた場合の方が洗浄効率は高い。これ は, pH 11 の電解水は他の水よりも布地への浸透性が高い ためと考えられる。つまり, 電解水では布地の繊維内部 まで水が浸透することができ，污れが布地より剥がれや すくなる作用があるものと考えられる。また，綿布では 他の素材に比べて各種の水による差が比較的大きく現れ やすい傾向も見られる。つまり, 綿と水は親和性が非常 に高いため，水の種類による影響が出易い。一方，ポリ エステル布やアクリル布では, 疎水性であるために水の 種類による差が生じ難かったことを示している.

また, 污垢成分の異なる 2 種類の綿の人工污染布を比 較すると, pH 11 の電解水を洗濯に用いることによって, 洗浄効率がどちらも高くなっていることがわかる(表 4). このことから, 污垢成分が異なっていても電解水の有効 性が確かめられた。

次に, DBS を添加して各々の洗濯を実施した（表 4). その結果, $\mathrm{pH} 11$ の電解水に界面活性剂を添加した場合に おいて最も洗浄効率が高く, 污れをよく除去しているこ とがわかる。ここで注目されることは，電解水にDBSを 添加することにより，DBS を添加しない場合に比べて洗 浄効率が高くなっていることである。 また, 電解水に対 する DBS 添加量が多い方が，洗浄効率は高くなっている.

一般に, 電解水の洗浄メカニズムとして, 発生した活 性酸素や次亜塩素酸ナトリウムの働きが指摘されている. しかし, 本実験で用いた電解水生成器は, 陽極液と陰極 液が隔膜を介して分離されたものである。そのため, ア ルカリ性電解水には次亜塩素酸イオンやその他の活性酸 素種は含まれない。事実, 本実験のアルカリ性電解水 (pH 11)に対してヨウ素滴定による分析を行なったところ, 残留塩素は全く検出されなかった. 表 4 から明らかなよ うに, 電解水にDBS を添加すると添加しないものに比べ て洗浄効率が高くなっている.また, 次亜塩素酸ナトリ ウムを添加しても吸水速度は全く変化しなかった (3.2 項). このことより, 電解水を洗濯に用いた場合の洗浄作用と しては, 活性酸素や次亜塩素酸ナトリウムの発生が寄与 しているのではないことがわかった。

さらに，綿の人工污染布を用いて，DBS 濃度と洗浄効 率の関係について調べた。その結果を図 6 に示す。どの 水においても DBS 濃度が高くなるに従って, 洗浄効率は 高くなった。 pH 11 の電解水は, 全ての DBS 濃度領域に おいて他の水よりも洗浄効率が高かった。また, $\mathrm{pH} 11$ の 電解水において, DBS 濃度が $1.6 \times 10^{-4} \mathrm{~mol} / 1$ 以下の領域で 
Table 4 Detergent efficiency for different artificial soiled fabrics after laundering.

\begin{tabular}{|c|c|c|c|c|c|c|}
\hline \multirow{2}{*}{$\begin{array}{l}\text { Artificial } \\
\text { soiled fabric }\end{array}$} & \multirow{2}{*}{$\begin{array}{l}\text { Concentration of } \\
\text { DBS }(\mathrm{mol} / \mathrm{l})\end{array}$} & \multicolumn{3}{|c|}{ Electrolysis water } & \multirow{2}{*}{ Distilled water } & \multirow{2}{*}{$\begin{array}{l}\mathrm{NaOH} \text { solution } \\
\quad(\mathrm{pH}=11)\end{array}$} \\
\hline & & $\mathrm{pH}=7$ & $\mathrm{pH}=9$ & $\mathrm{pH}=11$ & & \\
\hline \multirow{3}{*}{ Cotton $^{* 1)}$} & without & 20 & 22 & 33 & 10 & 18 \\
\hline & $1.6 \times 10^{-4}$ & 20 & 27 & 35 & 22 & 29 \\
\hline & $5.0 \times 10^{-4}$ & 35 & 36 & 47 & 35 & 37 \\
\hline \multirow{3}{*}{ Cotton $^{* 2)}$} & without & 17 & 18 & 21 & 13 & 18 \\
\hline & $1.6 \times 10^{-4}$ & 21 & 23 & 28 & 17 & 25 \\
\hline & $5.0 \times 10^{-4}$ & 45 & 45 & 47 & 44 & 45 \\
\hline \multirow{3}{*}{ Polyester ${ }^{* 2}$ ) } & without & -1 & -1 & 0 & -1 & 0 \\
\hline & $1.6 \times 10^{-4}$ & 3 & 3 & 3 & 0 & 1 \\
\hline & $5.0 \times 10^{-4}$ & 16 & 12 & 23 & 11 & 21 \\
\hline \multirow{3}{*}{ Wool $^{* 2)}$} & without & 6 & 6 & 21 & 5 & 19 \\
\hline & $1.6 \times 10^{-4}$ & 19 & 23 & 26 & 18 & 25 \\
\hline & $5.0 \times 10^{-4}$ & 46 & 45 & 53 & 44 & 44 \\
\hline \multirow{3}{*}{ Silk $^{* 2)}$} & without & 7 & 10 & 16 & 5 & 14 \\
\hline & $1.6 \times 10^{-4}$ & 23 & 26 & 27 & 22 & 25 \\
\hline & $5.0 \times 10^{-4}$ & 23 & 24 & 26 & 22 & 24 \\
\hline \multirow{3}{*}{ Acryl ${ }^{* 2)}$} & without & 2 & 3 & 5 & 0 & 4 \\
\hline & $1.6 \times 10^{-4}$ & 9 & 11 & 14 & 6 & 11 \\
\hline & $5.0 \times 10^{-4}$ & 17 & 18 & 23 & 17 & 20 \\
\hline
\end{tabular}

は，電解水と蒸留水の洗浄効率の差が特に大きい。ここ で注目されることは，DBSを添加していない電解水 $(\mathrm{pH}=11)$ の場合の洗浄効率が, 蒸留水に DBS を $1.6 \times 10^{-4}$ $\mathrm{mol} / \mathrm{l}$ 添加した場合よりも高いことである。例えば，綿の

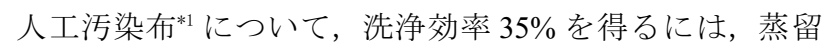
水を使用した場合には DBS $5.0 \times 10^{-4} \mathrm{~mol} / /$ 添加する必 要があるのに対し, $\mathrm{pH} 11$ の電解水では $1.6 \times 10^{-4} \mathrm{~mol} / 1$ で 良いことになる。また, pH 11 の電解水は, 界面活性剂の 濃度が低い場合において, 洗浄効率が蒸留水に比べて高 く現れやすいこともわかった。

\section{4 洗濯後の布地の損傷状態}

各種の水を用いて洗濯を行った場合の布地に対する損 傷について調べた。表 5 に, DBS を添加しないで洗濯し

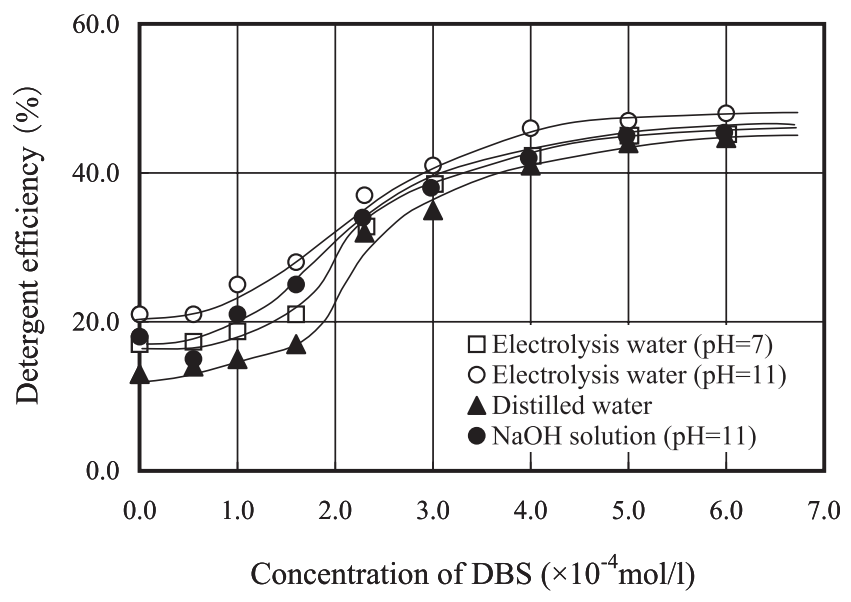

Fig. 6 Relationship between detergent efficiency and concentration of sodium dodecyl-benzenesulfonate for different water (Artificial soiled cotton fabric by Testfabrics Inc.).
た後の人工污染布の写真を示す. 繊維素材として, 綿, ポリエステル, ウールの結果を示寸，その結果，布地の 周りをかがり縫いをしていないために多少の解れはある ものの, 綿布やポリエステル布の場合では電解水の $\mathrm{pH}$ が 高くなっても洗濯後の布地に損傷はあまり認められな かった。特にポリエステル布では全く認められなかった。 このことは, 綿布やポリエステル布は耐アルカリ性が比 較的高いためと考えられる。

ウールの人工污染布の場合では, $\mathrm{pH}$ が 7 や 9 の電解水 では蒸留水の場合と殆ど同程度であった。しかし, pH 11 の電解水になると洗濯後の布地にかなり損傷が見られる. つまり, 人工污染布の端がほつれてきて, 布地が極端に 小さくなっていることがわかる. また, 水酸化ナトリウ 厶水溶液 $(\mathrm{pH}=11)$ の場合でもかなりの損傷が認められ, その程度はほぼ同程度であると云える。つまり, ウール は耐アルカリ性に劣るためと考えられる。電解水であっ ても繊維を損傷することは, アルカリ性水溶液の場合と 同じである．このことは，アルカリ性の電解水を洗濯に 用いる場合には, 繊維素材によっては使用を避ける必要 があることを示している。しかし， ウールと同様に耐ア ルカリ性が劣ると云われている絹の場合では，あまり損 傷が認められなかった。 その理由については, さらに検 討する必要がある.

\section{5 実際の洗濯を想定した洗浄効果}

前述のように繊維素材による差異はあるものの, 人工 污染布を用いた洗濯実験によって電解水による洗浄効果 が確認できた。しかし，より実際の使用を想定した洗濯 効果についても調べる必要がある。 そこで, 食品由来の 污れと, 洗濯中の再污染についての検討を行った. 
Table 5 Artificial soiled fabrics after laundering without detergent (Artificial soiled fabrics made by Testfablics Inc.).

\begin{tabular}{|c|c|c|c|c|c|c|}
\hline \multirow{2}{*}{$\begin{array}{c}\text { Artificial } \\
\text { soiled fabric }\end{array}$} & \multirow{2}{*}{$\begin{array}{c}\text { Before } \\
\text { laundering }\end{array}$} & \multicolumn{3}{|c|}{ Electrolysis water } & \multirow{2}{*}{ Distilled water } & \multirow{2}{*}{$\begin{array}{l}\mathrm{NaOH} \text { solution } \\
\quad(\mathrm{pH}=11)\end{array}$} \\
\hline & & $\mathrm{pH}=7$ & $\mathrm{pH}=9$ & $\mathrm{pH}=11$ & & \\
\hline \multicolumn{7}{|l|}{ Cotton } \\
\hline \multicolumn{7}{|l|}{ Polyester } \\
\hline Wool & & & & & & 5 \\
\hline & & & & & & \\
\hline
\end{tabular}

Table 6 Detergent efficiency of soiled fabrics with synthetic food colours after laundering (without DBS).

\begin{tabular}{|c|c|c|c|c|c|c|}
\hline \multirow{2}{*}{ Fabric } & \multirow{2}{*}{ Soil } & \multicolumn{3}{|c|}{ Electrolysis water } & \multirow{2}{*}{$\begin{array}{c}\text { Distilled } \\
\text { water }\end{array}$} & \multirow{2}{*}{$\begin{array}{l}\mathrm{NaOH} \text { solution } \\
\quad(\mathrm{pH}=11)\end{array}$} \\
\hline & & $\mathrm{pH}=7$ & $\mathrm{pH}=9$ & $\mathrm{pH}=11$ & & \\
\hline \multirow{3}{*}{ Cotton } & Amaranth ${ }^{* 1)}$ & 92 & 94 & 96 & 93 & 95 \\
\hline & & & & & & \\
\hline & Tartrazine $^{{ }^{* 2)}}$ & 90 & 95 & 100 & 90 & 97 \\
\hline \multirow{3}{*}{ Polyester } & Amaranth ${ }^{* 1)}$ & 95 & 96 & 100 & 94 & 98 \\
\hline & & & & & & \\
\hline & Tartrazine $^{* 2)}$ & 95 & 100 & 101 & 90 & 98 \\
\hline
\end{tabular}

污れ物質の一つとして，合成食用色素である食用赤色 2 号 (Amaranth) と食用黄色 2 号(Tartrazine)を用い，それら を所定濃度に希釈した水溶液に綿布とポリエステル布を 污染した。これらの合成食用色素は共に水溶性である. 風乾後の各々の污染布に対して洗濯を実施した(表 6). そ の結果, pH 11 の電解水では, 表 4 に示した人工污染布の 場合と同様に他の水に比べて污れがよく除去されている ことがわかった。 また, pH 11 の電解水を用いた場合では, 洗浄効率がほぼ $100 \%$ の值を示していることがわかる。こ のことから, 水溶性の合成食用色素の污れに対しては, pH 11 の電解水を洗濯に用いることで, 界面活性剂を全く 添加しなくても污染前の状態にまで污れを除去出来るこ とがわかった。

次に, 電解水を用いた場合の洗濯中の再污染について も検討を行った。そこで, 各種の水に污れのモデル物質 として疎水性の固体粒子のカーボンブラックと親水性の $\alpha$-酸化鉄 (III) を添加して擋拌し, 綿やポリエステルの白 布を入れて洗濯を実施した。そして洗濯後の織物の再污 染率を測定し, 用いた水との関係について調べた。その 結果を表 7 に示す.
綿布の場合, 電解水を洗濯に用いると蒸留水の場合に 比べてカーボンブラック， $\alpha$-酸化鉄 (III) の場合とも再污 染率が $2 \%$ ～3\% 程度低く現れた。 しかしながら綿布の場 合では，両方の污れ物質の場合とも水の種類による再污 染率の差は比較的小さかった。このことは, 綿布は親水 性繊維であるため, どの水においても布地への吸水性が 高いためであると考えられる。また， $\alpha$-酸化鉄 (III) での 再污染率は, カーボンブラックに比べてどの水において も $20 \%$ 程度低かった。このことは， $\alpha$-酸化鉄 (III) は水溶 性の固体粒子であるために固体粒子が洗濯水中に溶け出 し易く，布地を污染しにくかったためと考えられる。

次に, 疎水性のポリエステル布に対しても再污染につ いて検討した。その結果, ポリエステル布の場合でも, 綿布と同様に $\mathrm{pH} 11$ の電解水は蒸留水に比べて再污染率 が低かった。特に污れ物質にカーボンブラックを用いた 場合では, pH 11 の電解水の再污染率は蒸留水の場合に比 心゙て $22 \%$ 程度も低く現れた. また, 污れ物質に $\alpha$-酸化鉄 （III）を用いた場合でも, $\mathrm{pH} 11$ の電解水は蒸留水に比べて 4\% 程度と, 僅かではあるが再污染率が低かった。このこ とより, 洗濯に電解水を用いることで, 親水性繊維, 疎 
Table 7 Soil redeposition ratio for different soil and fabrics.

(Unit : \%)

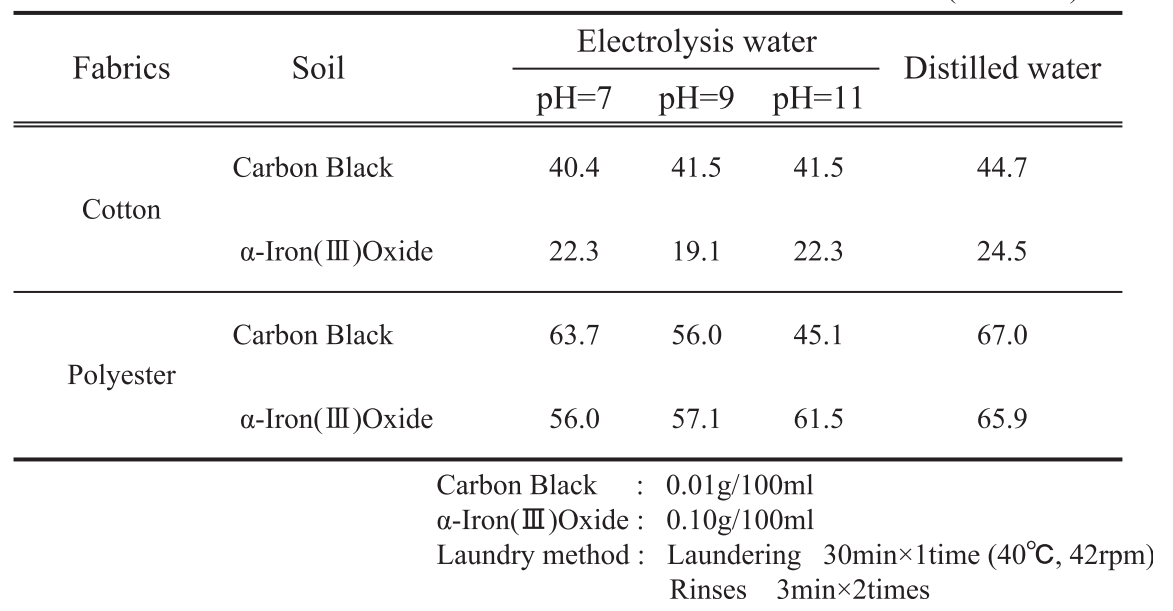

水性繊維とも洗濯中の再污染防止に界面活性剂を添加し ていない場合においては有効であることがわかった。

\section{4. 結 言}

洗濯における電解水の洗浄作用について詳細に検討し た. 以下に，その結果をまとめる.

（1）電解水の接触角は, セロハン, PET フィルムのどち らかであっても $\mathrm{pH}$ が高くなるに従って小さくなった. 特に, pH 11 の電解水では非常に小さく, 30 分後には セロハンにほぼ完全に吸収された。また，各種の水の 布地への吸水速度を調べたところ, pH 11 の電解水では 他の水に比べて吸収速度が高く, 布地への浸透性が非 常に大きいことがわかった。

（2）各種の水を用いて洗濯を行ったところ, 親水性素材 である綿, 絹, ウールの人工污染布の場合では, $\mathrm{pH} 11$ の電解水を用いることによって洗浄効率が高く現れた。 一方, 疎水性のポリエステル, アクリルの人工污染布 では, pH 11 の電解水で洗濯しても洗浄効率の向上は僅 かであった。

（3）各種の水を用いて洗濯した後の布地の損傷状態を調 べた. その結果, $\mathrm{pH} 11$ の電解水ではウール布の損傷が 認められた。 この結果は, 水酸化ナトリウム水溶液 $(\mathrm{pH}$ =11)の結果と同程度であり, 電解水であっても耐アル カリ性に劣るウールでは損傷の危険があることを示し ている。但し，同じタンパク質系の天然繊維である絹 布の場合では，損傷が認められなかった。

（4）水溶性や油溶性污れのモデル物質を用い, 綿布やポ リエステル布の再污染性を調べた. その結果, 洗濯に $\mathrm{pH}$
11 の電解水を用いると, 界面活性剤を添加していない 場合において蒸留水よりも再污染し難いことがわかっ た。また，水溶性の合成食用色素の污れに対しても， 污れの除去に界面活性剤を添加していない場合におい て有効であることもわかった。

\section{文 献}

1. V. Misra, G. Chawla, V. Kumar, H. Lal and P. N. Viswanathan, Ecotoxicol. Environ. Saf., 13, 164-168 (1987).

2. M. Kikuchi, Bulletin of Synthetic Detergent Research Association, 19, 3-6 (1995).

3. M. Kondo, M. Nagata and M. Nagayama, Journal of Japanese Association for Clothing Studies, 39, 133-140 (1996).

4. S. Fujiwara, K. Yamada, O. Nishimura and R. Sudo, Japanese Journal of Water Treatment Biology, 18, 44 (1998).

5. K. S. Ong and M. G. Degraeve, A. R. Silva-Wilkinson, W. J. Mccabe, L. W. Smith, Environ Toxicol Chem, 15, 138143 (1996).

6. N. Hamada, Life sanitation, 49, 108-113 (2005).

7. M. Higashinaka and J. Kawai, Bulletin of Consumer Science Research Institute of Hyogo Prefecture, No.18, 4767 (2003).

8. ECO INDUSTRY, 7, 55-57 (2002).

9. Y. Ohtake, Metal, 67, 162-163 (1997). 